OPTIMUM. STUDIA EKONOMICZNE NR 5 (65) 2013

\author{
Elżbieta Izabela MISIEWICZ1
}

\title{
THE INFLUENCE OF CHANGES IN PERSONAL INCOME TAX REGULATIONS ON DONATING NON-PROFIT ORGANIZATION
}

\begin{abstract}
Summary
Each entity paying taxes would like to have real influence on the way of their allocation. Since 2004 in Poland payers of personal income tax were able to decide about donating 1 percent of personal income tax to a chosen public benefit organization for the first time. Since the introduction of the possibility of donating non-profit organization (NPO) tax regulations were repeatedly modified. Did tax-payers willingly use the ability to decide who they should donate their 1 percent of personal income tax to? In what way did changes of tax regulations influence taxpayers' decision? In order to answer those questions soft modelling was used, which allowed to examine the influence of changes in regulations relating to 1 percent of personal income tax on taxpayers' decision.
\end{abstract}

Key words: taxpayers' behaviuor, changes in tax regulations, 1 percent tax

\section{Introduction}

The initiative, which has been in force in Poland since 20042, allowing the taxpayers to decide on what purpose 1 percent of their personal income tax will be spent is not a novum. As early as in postwar years Spain and Italy permitted their citizens to donate a part of their taxes to Catholic Church. Since 1997 by virtue of the act on public benefit from 1996 Hungarian citizens were given the possibility to donate 1 percent of their personal income tax to chosen non-governmental organization, and since 1998 they can additionally donate 1 percent of their personal income tax to chosen church [Makowski, 2007]. Somewhat later than in Hungary in year 2000 in Slovakia there was passed an act on individual income tax, which predicted an ability to transfer 1 percent (currently 2 percent) of taxes in aid of non-governmental organizations.

Initially in Poland, in accordance with the act, only personal income taxpayers who individually filled in the tax form and also taxpayers paying lump sums on registered income could lower their income tax resulting from the tax return form by amount not

${ }^{1}$ Elżbieta Izabela Misiewicz, Ph.D. - Faculty of Economics and Management, University of Bialystok; e-mail: elzbieta-misiewicz@wp.pl.

2 Regulations concerning subsidizing the NPO in Poland are set out in the Act of 24 April 2003 on Public Benefit and Volunteer Work (Journal of Laws of 2003 No. 96, item. 873). 
exceeding 1 percent of personal income tax and donate it to a selected NPO. Since 2007 from a taxpayer's point of view, public benefit organization's support principles were simplified in a significant way, because having calculated 1 percent of personal income tax the taxpayer does not have to do a transfer on his own if he puts the counted amount, NPO name and KRS number while filling in PIT form, since it is the Tax Office that will take care of distribution of the tax..

The aim of the article is to examine taxpayers' reactions to changes of the 1 percent personal income tax regulations. In order to make such analysis there was used the soft model [Wold, 1980; Rogowski. 1990; Mierzyńska, 1999], which is the generalized econometric model allowing to examine relationships between unobservable variables. The model was estimated basing on the data from the period 2003-2011 coming from the Ministry of Finance.

\section{Specification of the soft model}

Each soft model consists of two submodels: internal and external. The first one determines the scheme of dependence between hidden variables, while the second one comprises definitions of hidden variables [Rogowski, 1990, p. 33]. The external model describes relations between unobservable variables and their indicators. Hidden variables can be defined in two ways: deductively and inductively. In the first case it is assumed that latent variable as a theoretical concept is a starting point to empirical data research, thus it is a prior indicator in relation to a given indicator. Ratios of such hidden variables are called reflective. They are supposed to be characterized by a high correlation between each other, because they react to changes of the same value. In the second inductive case, there occurs transfer from observable to hidden variables, while indicators are said to be emergent indicators [Perło, 2004, p. 137-138]. While creating models with unobservable variables, one should define connections between indicators and theoretical variable in the first place. Making the decision concerning choosing the type of indicators, which are included in the model, should result from previously accepted theoretical description [Rogowski, 1990, p. 25].

Internal relations in soft models have linear characteristics. An internal model accepted in presented analysis has got the following form:

$$
T P D_{t}=\alpha_{0}+\alpha_{1} C_{H T R}+\varepsilon_{t}
$$

where:

$T P D_{t}$ - tax-payers' decision,

$\mathrm{TRC}_{t}-$ tax regulations changes,

$\alpha_{0}, \alpha_{1}$ - model parameters,

$\varepsilon_{t}$ - random factor.

Both, internal and external model was presented on the Diagram1. 


\section{Soft model}
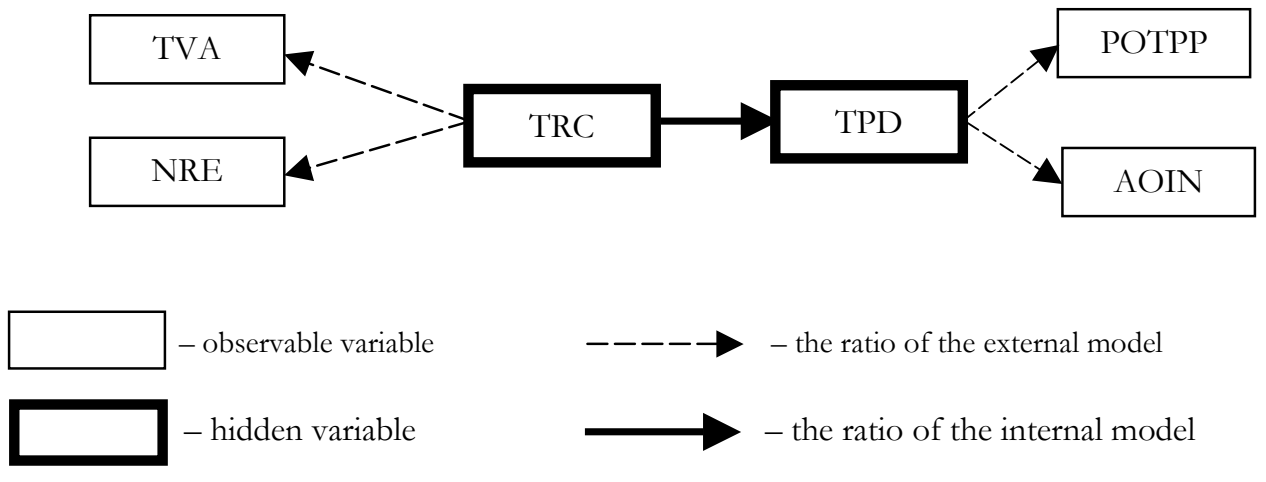
- observable variable

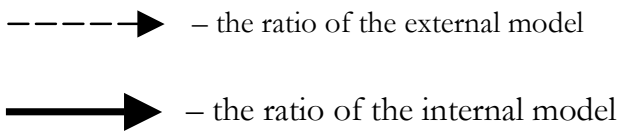

Source: Author's own elaboration

There are two hidden variables described in the model: changes in tax regulations (TRC) as well as taxpayers' decision (TPD) (indicator description is included in the Table 1).

\section{Indicators of hidden variables}

TABLE 1.

\begin{tabular}{|l|c|l|}
\hline \multicolumn{1}{|c|}{ Hidden variable } & $\begin{array}{l}\text { Symbol } \\
\text { indicator }\end{array}$ & \multicolumn{1}{c|}{ Meaning } \\
\hline $\begin{array}{l}\text { Tax regulations } \\
\text { changes (TRC) }\end{array}$ & TVA & $\begin{array}{l}\text { time variable } \\
\text { new principles of obligatory regulations of 1 } \\
\text { percent personal income tax }\end{array}$ \\
\hline $\begin{array}{l}\text { Tax-payers' decision } \\
\text { (TPD) }\end{array}$ & POTP & $\begin{array}{l}\text { the percentage of taxpayers, who declare income } \\
\text { by general rules and donate 1 percent of personal } \\
\text { income tax } \\
\text { the amount of income on the accounts of public } \\
\text { benefit } \\
\text { organizations expressed as personal income tax } \\
\text { percentage }\end{array}$ \\
\hline
\end{tabular}

Source: author's own elaboration.

Tax regulations changes (TRC) were defined by two indicators. The one determined as new principles of obligatory regulations of 1 percent personal income tax donated to public benefit organizations (NRE) reflects tax regulations changes included in the Public Benefit Activity and Volunteer Work, which took place in 2007. In order to grasp and picture those changes, NRE ratio was defined as dummy variable. During the period 2003-2006, while less advantageous for taxpayers regulations were still obligatory, the variable new principles of obligatory regulations of 1 percent personal income tax (NRE) takes value ' 0 ' and ' 1 ' in the remaining period. Another indicator, the time variable (TVA) was expressed in years. As a result of including this indicator in the model, apart from tax regulation changes, 
there were also caught changes occurring in economy during the examined period, e.g.: inflation. Because the model was based on the data from 2003-211, the time variable takes values: 2003, 2004, 2005, 2006, 2007, 2008, 2009, 2010 and 2011.

Similarly to changes in tax regulations, the second of unobservable variables, that is taxpayers' decision (TPD), was as well defined by two indicators: the percentage of taxpayers who declare income by general rules and donate 1 percent of personal income tax NPO (POTP) as well as the amount of income on the accounts of public benefit organizations expressed as personal income tax percentage (AOIN).

During the first year of existence of mandatory provisions of the public benefit activity and service act only insignificant amount of taxpayers, just 0.34 percent of entitled to do so, decided to donate 1 percent of personal income tax to a chosen public benefit organization. Year by year the situation improved and taxpayers were more likely to support NPO (Diagram 2).

DIAGRAM 2.

\section{The share of tax-payers accounting according to general rules, who sup- ported NPO with 1 percent of output (in \%)}

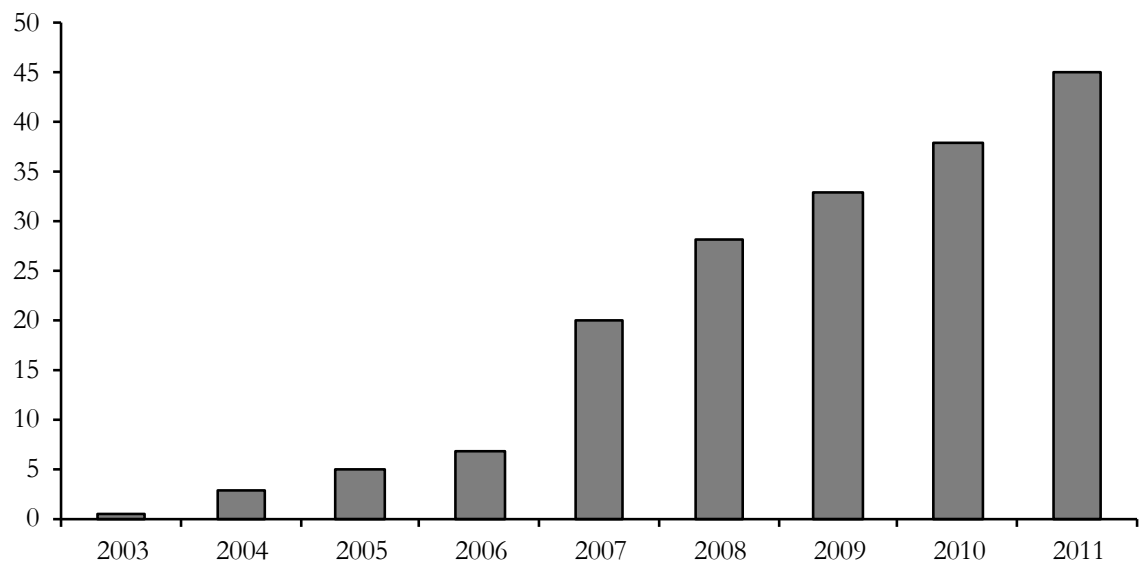

Source: [Informacja dotyczaca kwot 1\% naleĩnego podatku..., 2011, s. 6].

In 2006, the last year when the old rules were still valid, only about 7 percent of taxpayers, who could reduce their taxes to donate to NPO, did it. In the following year, i. e. the first year after the change of tax regulations there were nearly three times as many taxpayers who agreed to make a donation, that is approximately 20 percent, in 2008 almost 28 percent. Since 2008 the number of tax-payers donating 1 percent of personal income tax to NPO increases to about 5 percentage points per year. According to data from 2011 nearly 43 percent of tax-payers accounting to general principles donated 1 percent of personal income tax to NPO.

Similarly to the number of tax-payers accounting according to general rules, who supported NPO with 1 percent of personal income tax, in the initial period of the 
existence of public benefit organization and service act, the share of amounts from 1 percent of personal income tax was on a really low level. In 2003 NPO taxpayers donated only 0.03 percent of personal income tax. The greatest increase of the amount constituting 1 percent of personal income tax took place right after the introduction of new regulations i.e. 2007 (in 2006: 0.28 percent while in 2007: 0.64 percent). In 2011 the amount which was donated to public benefit organizations by taxpayers made up 0.71 percent of personal income tax. Shaping the share level of amount donated to NPO by taxpayers expressed as personal income tax percentage in years 2003-2011 is pictured in Diagram 3.

DIAGRAM 3.

The share of amount donated by NPO tax-payers expressed as personal income tax percentage (in \%)

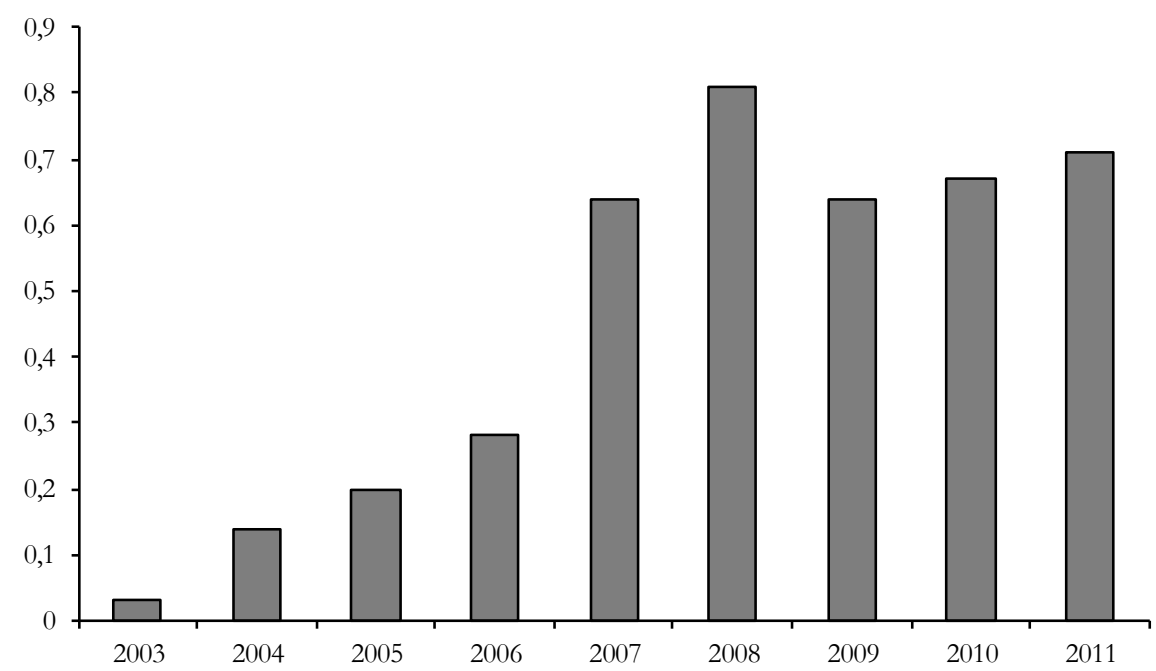

Source: [Informacja dotyczaca kwot 1\% naleinnego podatku..., 2011, s. 6].

\section{Estimation and verification of the model}

The soft model was estimated by the partial method of the smallest squares, which allows concurrent obtaining of the parameters' assessment of the internal and external model. As a result of estimation the following assessment of parameters of internal relations was received (estimation errors were presented in the brackets).

$$
\hat{T P D_{\mathrm{t}}}=+\underset{(0.0229)}{0.9942} T R C_{\mathrm{t}}-\underset{(8.8244)}{398.881} \quad \mathrm{R}^{2}=0.9881
$$

Estimations of model parameters meet the expectations. The number value at the parameter TRC is 0.9942 which means significant influence of tax regulations changes referring to one percent of personal income tax on taxpayers' behavior. 
In the above model the parameters are considerably non-zero and the value of the coefficient of determination $\mathrm{R}^{2}$ is 0.9881 , which means a very good adjustment to estimated values of hidden variables.

As indicators occurring in the models are reflective indicators, the analysis of variables is done on the basis of factor loadings. These loadings are correlation coefficients among unobservable variable and its indicators, which were compiled in the Table 2, in Diagram 4. and in Diagram 5.

TABLE 2.

Estimating parameters of external relations in the soft model

\begin{tabular}{|l|c|c|}
\hline \multicolumn{1}{|c|}{ Hidden variable } & Symbol indicator & $\begin{array}{c}\text { Factor loadings } \\
\text { (standard error) }\end{array}$ \\
\hline Tax regulations changes (TRC) & TVA & $\begin{array}{c}0.9658 \\
(0.0005)\end{array}$ \\
\cline { 2 - 3 } & NRE & $\begin{array}{c}0.9661 \\
(0.0005)\end{array}$ \\
\cline { 2 - 3 } $\begin{array}{l}\text { Taxpayers' decision } \\
\text { (TPD) }\end{array}$ & POTP & $\begin{array}{c}0.9769 \\
(0.0063)\end{array}$ \\
& AOIN & $\begin{array}{c}0.9756 \\
(0.0071)\end{array}$ \\
\cline { 2 - 3 }
\end{tabular}

Source: Author's own elaboration based on the results of soft modeling.

DIAGRAM 4. Value of factor loadings of latent variable indicators changes in tax regulations

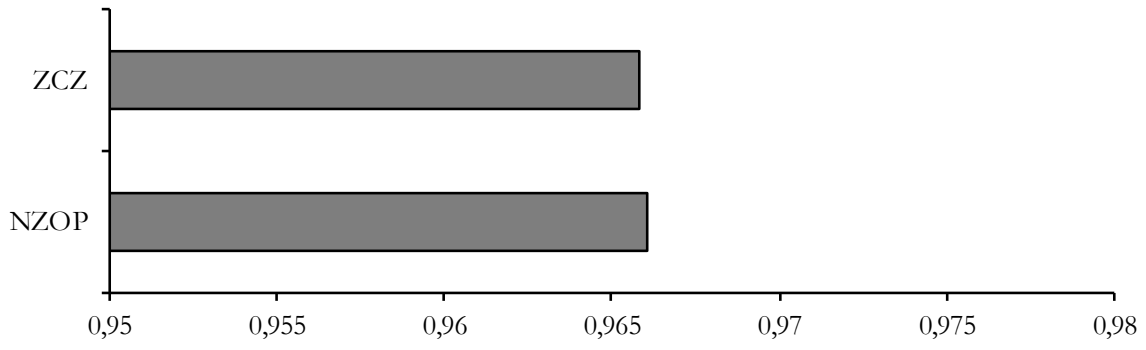

Source: Author's own elaboration based on the results of soft modeling

All ratios describing both hidden variables of this model are stimulants, so the increase of their values causes the growth of those variables. The variable of tax regulations changes is illustrated the best by new obligatory principles of 1 percent personal income tax acts $Z$ ratio (0.9661) and slightly less by time variable ratio (0.9658). The variable taxpayers decision is strongly presented by the percentage of taxpayers, who settle up according to general rules and donate 1 percent of personal income tax to NPO (0.9769), a bit 
weaker by the amount of sum, which was transferred to public benefit organizations' accounts expressed as personal income tax percentage (0.9756).

DIAGRAM 5. Value of factor loadings of latent variable indicators tax-payers' decision

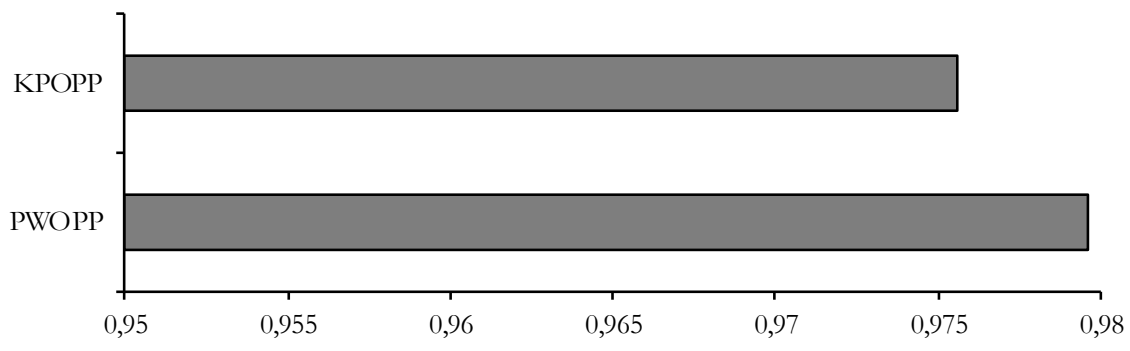

Source: Author's own elaboration based on the results of soft modeling.

Based on received soft model estimations referring to both external and internal relations the model was verified positively. Evaluations of models quality can also be done on the basis of Stone-Geisser's test, which verifies the model in terms of its usefulness in prediction.

TABLE 3

The value of the test Stone-Geisser general and for indicators

\begin{tabular}{|c|c|}
\hline Symbol indicator & The value of the test S-G \\
\hline POTP & 0.7956 \\
\hline AOIN & 0.7372 \\
\hline General value of S-G test & $\mathbf{0 . 7 9 5 5}$ \\
\hline
\end{tabular}

Source: Author's own elaboration based on the results of soft modeling

General value of S-G test as well as S-G values for particular hidden variable indicator are greater than zero, what gives evidence of good prognostic value of the model (table 3.).

\section{Analyzed of the results}

Using PLS method allows not only to estimate the relations between hidden variables, but also to estimate values of those variables. As a result we receive a synthetic variable whose values do not have substantial interpretation, but can be used in comparison analysis. Ratios of synthetic meter defining taxpayers decision were presented in Diagram 6. 
DIAGRAM 6.

\section{Values of synthetic meter}

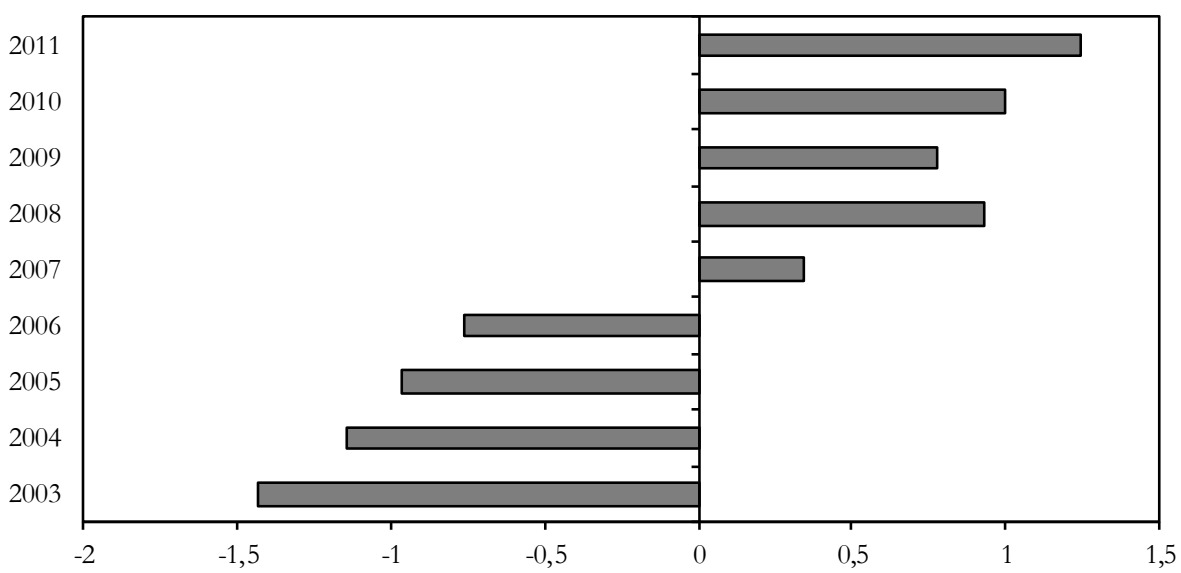

Source: Author's own elaboration based on the results of soft modeling.

It is necessary to remember, that the variable taxpayers' decision is mirrored by two ratios and that not only external model but the internal as well has impact on estimating its value.

In the first year of the existence of the act on public benefit activity and service there occurred the smallest over nine analysed years taxpayers' interest in such a form of donating NPO. It happened due to complication of the rules. Initially, principles relating to supporting NPO with 1 percent of personal income tax had a form of classic tax allowance. The taxpayer only after making a payment in favor of a chosen public benefit organization was able to count out not more than one percent of personal income tax. Such a construction surely did not have a beneficial effect on taxpayers' interest in this kind of donating NPO. It did not only require significantly higher activity, but also bearing additional costs and time, which had to be sacrificed in order to transfer specific amount to NPO in a proper way. One should also remember to archive a transfer confirmation, because such a document needs to be shown in case of inspection. What is more, the number of institutions having the status of a public benefit organization was really limited, because their registration started not until 1st January 2004.

Year by year the situation was improving. Not only did more and more people make a decision to donate 1 percent of personal income tax but there was also growth in values of donations transferred to NPO accounts. The biggest change in synthetic meter value took place in 2007, that is right after the modification of regulations. Those changes were mainly a result of simplifying the process of donating 1 percent of personal income tax to NPO, because since 2007 it has been The Revenue Office, not a tax-payer, which is responsible to transfer money specified in tax return to accounts of public benefit organizations. Apart from urgent reaction of taxpayers to changes of regulations regarding donating public benefit organizations with 1 percent of personal 
income tax, which took place in 2007, the years 2004 and 2008 were periods, when the growth of synthetic meter value defining taxpayers' decision was the highest. It means that tax-payers reacted rationally to changes in tax regulations, but with a certain lag. In 2009 the value of synthetic meter was lower than in 2008 , due to modifications of tax scale.

\section{Conclusion}

Soft modelling is one of methods used to examine relations occurring between unobservable variables. Received results show a very strong positive and statistically important dependence occurring between hidden variables. According to carried analysis, tax regulation changes variable was affected by modifications of tax regulations in 2007, which related to the way of changing the mechanism of allocation not directly from taxpayers but managers of The Revenue Office and with the extension of taxpayers' circle, who could use this form of supporting socially useful activity.

It is necessary to remember that when estimating the soft model using PLS method there are also received estimations of values of directly unobservable variables, which even though lack substantial interpretation are used in comparison analysis. Estimations of hidden variables allowed to capture those periods, when taxpayers reacted the hardest on modification of tax regulations and formulating a statement that tax-payers react to all changes rationally, but with a delay.

\section{Bibliography}

Informacja dotyczqca kwot 1\% należnego podatku dochodowego od osób fisycznych przęeazanych organizacjom po:̇ytku publicznego z. rozliczenia za 2011 rok, 2011, Ministerstwo Finansów, Warszawa.

Makowski G., 2007, Wiele twarsy jednego procenta, Instytut Spraw Publicznych, Warszawa.

Mierzyńska D., 1999, Modele miekkkie w analizie porównawczej żtożonych zjjawisk spoteczno ekonomicznych, rozprawa doktorska, Wydział Ekonomii i Zarządzania, Uniwersytet w Białymstoku, Białystok.

Perło D., 2004, Źródła finansowania rožwoju regionalnego, Wydawnictwo Wyższej Szkoły Ekonomicznej w Białymstoku, Białystok.

Rogowski J., 1990, Modele miekkeie. Teoria i zastosowanie w badaniach ekonomicznych, Wydawnictwo Filii UW w Białymstoku, Białystok.

Wold H., 1980, Soft Modelling: Intermediate between Traditional Model Building and Data Analysis, Banach Centre Publication, no. 6, Matematical Statistical. 